\title{
The pedagogical research project - an essential tool for the development of research competencies in the field of education
}

Florentina Mogonea \& Florentin Remus Mogonea 


\title{
The pedagogical research project - an essential tool for the development of research competencies in the field of education
}

\author{
Florentina Mogonea $^{a}$, Florentin Remus Mogonea ${ }^{{ }^{*}}$ \\ ${ }^{a}$ University of Craiova, 13, A.I. Cuza Street, Craiova, 200585, Romania \\ *Corresponding author: mogoneaf@yahoo.com
}

\section{Abstract}

Keywords: research design competencies; research project; research design.
The formation of the competencies necessary in the field of educational research implies both the acquisition of knowledge regarding this field and the specifics of the researches carried out here, as well as the capacities, the abilities to design different researches, on various topics, present and of interest, to carry them out, to monitor all the actions aimed at achieving the proposed finalities, validating hypotheses, finalizing the research undertaken, disseminating the results, capitalizing on them. To these, we add the development of an appropriate attitude, keeping to the principles of scientific ethics.

We consider the design phase to be particularly important for the success of it. The instrument that materializes the design activity of the research, the research project represents a unitary, coherent and logical structure of all the steps and actions that will be undertaken.

The present study aims to analyze the importance of this tool in the initial teacher training process, where training in the field of educational research has to occupy an important place. We used two research methods: the questionnaire survey and the analysis of the product activity. The sample of subjects was made up of 83 MA students from the Faculty of Letters, which also run in parallel with the Masters Program, the Psycho-pedagogical Training Program, level II and, within it, the Methodology of Educational Research discipline.

The results obtained from the investigation confirmed the value of the pedagogical research project in the formation of the researcher's competencies of the future teacher students.

\section{Schlüsselworte:}

Kompetenzen zum

Planen der

Forschung;

Forschungsplan;

Design der

Forschung.
Die Bildung der notwendigen Kompetenzen für Bildung sieht die Aneignung von Kenntnissen über dieses Gebiet und Besonderheiten der hier geleisteten Forschungen vor, aber auch Fähigkeiten und Fertigkeiten zum Planen von verschiedenen Forschungen über verschiedene heutige und Interessenthemen, bzw. die Durchführung dieser Forschungen, Überwachen aller Schritten zum Erreichen der gezielten Ergebnisse, Validierung der Voraussetzungen, Beenden der vorgenommenen Forschungsmassnahmen, Verbreiten und Verwerten der Ergebnisse. Zudem vermerken wir auch die Entwicklung eines passenden Verhaltens unter Einhalten der Voraussetzung der wissenschaftlichen Ethik.

Finden wir die Planung der Forschung als sehr wichtig zum Erfolg der Forschung. Das Werkzeug zur Planung der Forscjung, bzw. der Forschungsplan, ist eine einheitliche kohärente und logische Struktur aller zum Durchführen notwendigen Schritten und Handlungen.

Das heutige Studium sieht die Überprüfung der Wichtigkeit dieses Werkzeuges zur ursprünglichen Bildung der Lehrer vor, wobei die Bildung im Gebiet der Bildungsforschung eine wesentliche Rolle spielt.

Ich habe zwei Forschungsmethoden angewendet: Befragungsbogen und Analyse der Ergebnisse der Tätigkeit.

Die befragenen Personen bestand aus 83 Masterstudenten von der Fakultät für Literaturwissenschaft, die zugleich zu dem Masterat auch die Bildung im Bereich der Psychopädagogie, Stand II, Fachbereich Methodologie der Bildungsforschung, besuchen.

Die infolge der Prüfung erzielten Ergebnisse bestätigten den Wert des Forschungsplanes zur Bildung der Forschungskompetenzen der künftigen Lehrer.

\section{Introduction}

The initiation of research in the field of education is a challenge for any teacher, even for those with experience in the field, even more so in the case of the debutants or the ones who are during their initial professionalisation period. The importance of this segment of a teacher's training, despite a certain degree of difficulty, makes it necessary to pay increased attention even from the beginning stage of the initial teacher education. The carrying out of some pedagogical research requires first of all a good knowledge of the specificity of the scientific research, a very close connection with the educational practice, in order to be able to then design and carry out such steps that have the purpose of improving the didactic 
activity, the development of the field from a theoretical and a praxeological perspective.

Each stage of research is important and must be approached with maximum rigor and integrated in the general context of the whole process. Due to the complexity of the research, the multitude of variables involved, the need to manage them properly and minimize the possibility of random occurrence, a proper and appropriate design is required.

The activity of designing some research which has itself a high degree of complexity, involves a joint, a harmonious and logical combination of all stages and components, so as to provide the premises for a successful pursuit.

A well-made research project does not implicitly guarantee the success of the research in question, but it is a condition for it.

The training of the designing skills of pedagogical research can be achieved even from the initial stage of the teachers' training. The first level of psycho-pedagogical training offers the possibility of initiating students in the field of research in disciplines such as Educational
Psychology or Pedagogy. The second level, being one of thoroughness, assures the development of the students' research competencies, especially in the Methodology of Educational Research discipline.

In the last mentioned discipline, first of all, the competency to design pedagogical research, through elaborating research projects, is practiced.

\section{The specifics of the designing activity of research in the field of education}

Any pedagogical research involves a series of stages, each of them summing up specific actions (Walliman, 2011; Seltman, 2012; Toshkov, 2018). Plomp (2013, p. 13), inventories several functions (roles) of the design of research: to describe; to compare; to assess; to explain or anticipate; to develop.

After choosing and formulating the theme, the elaboration of the research design is probably one of the most important decisions of the researcher (Abutabenjeh \& Jaradat, 2018).

F.R. Mogonea (2010, p. 40) and F. Mogonea (2013, pp. 79-80) present a possible structure of educational research (see table no. 1).

Table no. 1. The enterprise of (ameliorative) pedagogical research (Mogonea, 2010, p. 40,

\begin{tabular}{|c|c|c|}
\hline Stages & Substages & Conditions \\
\hline \multirow[t]{5}{*}{$\begin{array}{l}\text { A. Preparing the } \\
\text { research }\end{array}$} & $\begin{array}{l}\text { Choosing the research } \\
\text { problem }\end{array}$ & $\begin{array}{l}\text { It must be current, original, scientifically meaningful, well } \\
\text { motivated, accurately formulated; it must identify solutions for } \\
\text { improvement; it must be of general interest (and not of a personal, } \\
\text { individual one); it must know applicability, etc. }\end{array}$ \\
\hline & Documentation & $\begin{array}{l}\text { The study of the thematic bibliography, by source } \\
\text { categories; the foreign bibliographic resources, actual in the } \\
\text { problem; the critical presentation of the bibliographic aspects }\end{array}$ \\
\hline & $\begin{array}{l}\text { Establishing the } \\
\text { working hypothesis, } \\
\text { the purpose and the } \\
\text { objectives }\end{array}$ & $\begin{array}{l}\text { Establishing the working hypothesis ("if ... then ...", "the } \\
\text { more ...the better...", "it is possible to ... if", "what would happen if } \\
\ldots \text {...; the derivation of the particular hypotheses from the specific } \\
\text { hypothesis; the clear determination of the purpose and objectives of } \\
\text { the research, by work stages, etc. }\end{array}$ \\
\hline & $\begin{array}{l}\text { Establishing the } \\
\text { methodology }\end{array}$ & $\begin{array}{l}\text { Identifying the main methods to be used in the research, on } \\
\text { stages of work, establishing the place, the time, the samples } \\
\text { (experimental and control), setting the steps of the research, etc. }\end{array}$ \\
\hline & $\begin{array}{l}\text { Making the research } \\
\text { plan }\end{array}$ & $\begin{array}{l}\text { Making the research project that will prepare the stages, the } \\
\text { steps to follow. }\end{array}$ \\
\hline $\begin{array}{l}\text { B. The } \\
\text { implementation } \\
\text { of the research }\end{array}$ & $\begin{array}{l}\text { Applying the expected } \\
\text { interventions }\end{array}$ & $\begin{array}{l}\text { It assumes the implementation, the application of what was } \\
\text { proposed (independent variables), the pursuit of the purpose, the } \\
\text { objectives, the reformulation of the hypotheses, the tracking of the } \\
\text { differences between the samples, etc. }\end{array}$ \\
\hline \multirow[t]{2}{*}{$\begin{array}{l}\text { C. Completing } \\
\text { the research, } \\
\text { capitalizing on } \\
\text { results }\end{array}$} & $\begin{array}{l}\text { The quantitative and } \\
\text { qualitative data } \\
\text { processing and } \\
\text { interpretation }\end{array}$ & $\begin{array}{l}\text { It is done in the posttest and retest when data between } \\
\text { samples are compared quantitatively (statistically) and qualitatively } \\
\text { (psycho-pedagogically) and the conclusions are drawn. }\end{array}$ \\
\hline & $\begin{array}{l}\text { Capitalizing on } \\
\text { research and results }\end{array}$ & Dissemination, publication, generalization, enlargement \\
\hline
\end{tabular}


The research preparation phase ends with the development of the research project. We are going to present in what follows a possible structure of it (Bocoş, 2003, pp. 35-36):

- presenting the researched problem: definition; terminological delimitations, the clarification of the basic concepts, importance/ educational relevance; actuality; the motivation of choosing the theme;

- synthesizing the state of problem research, the solved issues and those that have not been satisfactorily solved, making critical analyzes by the researcher, anticipating its original contributions;

- presenting the basic, fundamental hypothesis and the secondary/auxiliary assumptions;

- presenting the purpose and objectives of the research

- describing the research methodology and concrete strategy used in the course of the actual research, which includes the following elements:

- the place of research;

- the period of research;

- the stages and the substages;

- the research strategy;

- the study subjects involved;

- the content sample (with arguments and explanations);

- the subjects/ pupils and their characterization: age, sex, general level of training, level of training in the discipline of interest, level of intellectual development, level of physical development, social descent, professional status and others;

- independent variables/ variables dependent variables/ variables and so on.

- the research methodology;

- the material resources used and the costs involved in the operational data collection tools,

- the strategy for verifying and evaluating the results obtained by the subjects;

- the methodology for the processing of research data, including electronic work tools;

- establishing the ways to capitalize on research.

Although algorithmic, the previously presented structure needs to be personalized according to the conditions under which it is exploited, the type of research, the pursued objectives, the sample of subjects, and the researcher's experience.

Depending on the type of research, of intentionality, both quantitative and qualitative methods can be used (Astalin, 2013; White \& Sabarwal, 2014; McKim, 2017; Mohajan, 2018; Janssens, Bos, Rosmalen, Wichers \& Riese, 2018). The two paradigms, that of research based on quantitative methods and the other on qualitative methods, must not necessarily be seen in opposition but in complementarity. The first, the quantitative one, is known as the paradigm of scientific research, the other as the paradigm of socio-anthropological research (Atieno, 2009 , p. 13). The selection of research methods and the development of the tools associated to them is an essential step in the unfolding of the research, which highlights one of the core competencies of a researcher, a competency that can be formed through initial professionalisation.

\section{The research methodology}

The aim of our research was to understand the role and importance of the pedagogical research project in the development of the future teacher students competencies in designing certain pedagogical research.

Derived from this goal, the objectives aimed at:

- knowing the students' opinion regarding the role of the discipline The methodology of the educational research in the formation of the competency to design some educational research;

- the self-evaluation of the research project, by reference to different stages or dimensions of the project;

- identifying the advantages and disadvantages of the pedagogical research project;

- the correlation of students' self-evaluation with the project evaluation, based on the evaluation scale.

The actions undertaken aimed to validate two hypotheses:

1. The pedagogical research project is a useful tool in forming the competency to design some educational research. 
2. The students can make an objective selfevaluation on the successful and unsuccessful aspects of the pedagogical research project.

\section{The research methodology}

In order to validate the previously mentioned hypotheses and to achieve the research objectives, we capitalized on two research methods, accompanied by appropriate tools: the questionnaire survey and the analysis of the activity products (of the research projects developed by the students).

The questionnaire applied to the MA students consisted of 14 items with closed, semi-closed answers and also a few open-ended items.

The items of the questionnaire aimed to investigate the opinion of the subjects regarding:

- the importance of the competency meant to design pedagogical research for a teacher;

- the role of the Methodology of educational research and of the research project in the formation;

- development of the competency of designing certain research in the field of education;

- the most successful and the least successful part of the research project;

- the difficulties encountered in: reasoning behind the choice of the theme; making the documentation; formulating the purpose and the objectives of the research; making the assumptions and variables; presenting the research methodology;

- The advantages and disadvantages of the pedagogical research project in the training of a future teacher's research competencies.

For the analysis of the research projects developed by the students, we used an evaluation grid whose indicators were grouped into four categories: on the choice and formulation of the theme and the motivation of choosing it; on the theoretical foundation of the theme; on the specification of the hypotheses and the objectives of the research; on the choice of the research methodology.

The sample of subjects was made up of 83 MA students from the Faculty of Letters, University of Craiova, in their first year. 18 students (representing
$21.69 \%$ ) of the sample included in the investigation are, at the same time, teachers.

\section{Results}

The results obtained after the application of the two research methods allowed the verification of the truth value of the two hypotheses mentioned above.

We are presenting, for the beginning, the results that allowed the validation of the 1 st hypothesis.

Thus, most of the students chose the first of the variants offered (to a large extent) when they answered the question about the importance of the competency necessary to design some pedagogical research, for a future teacher (see figure no. 1).

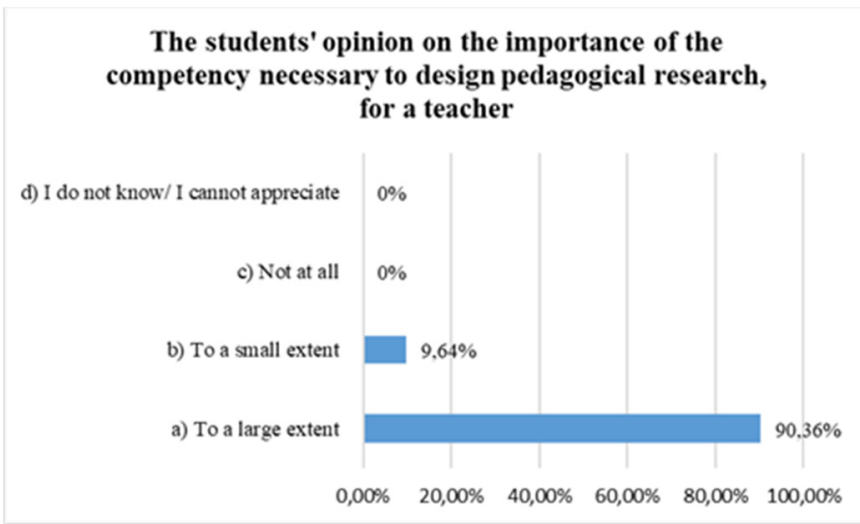

Figure no. 1. The students' opinion on the importance of the competency necessary to design pedagogical research, for a teacher

The results recorded in this item are similar to those in the item on the importance of the Methodology of Educational Research for the development of the design competency of research in the field of education

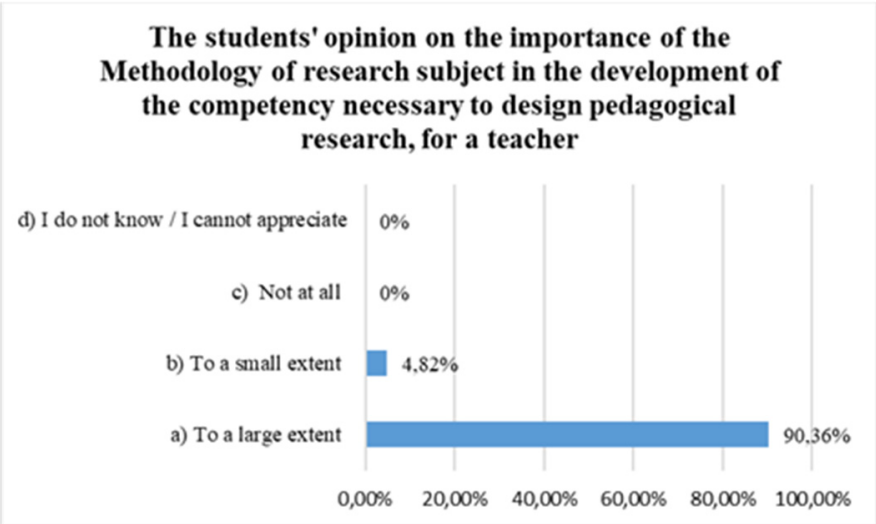

Figure no. 2. The students' opinion on the importance of the Methodology of research subject in the development of the 
competency necessary to design pedagogical research, for a teacher

The students consider the research project to be useful in forming the competency to design pedagogical research, as the results presented in figure no. 3 show.

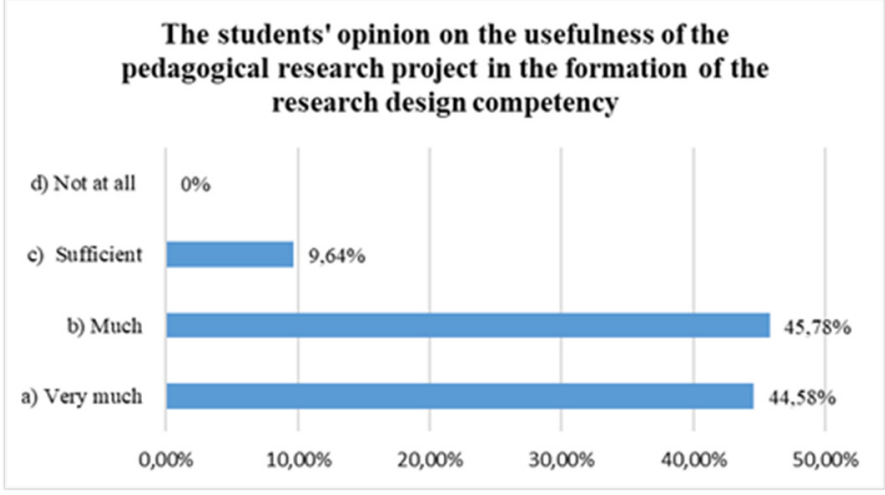

Figure no. 3. The students' opinion on the usefulness of the pedagogical research project in the formation of the research design competency

The following items of the questionnaire provided information able to ensure the validation of the second hypothesis of the research.

Regarding the complexity of the research project, the students appreciated that the documentation was the most complex part, as there can be seen in figure no. 4 .

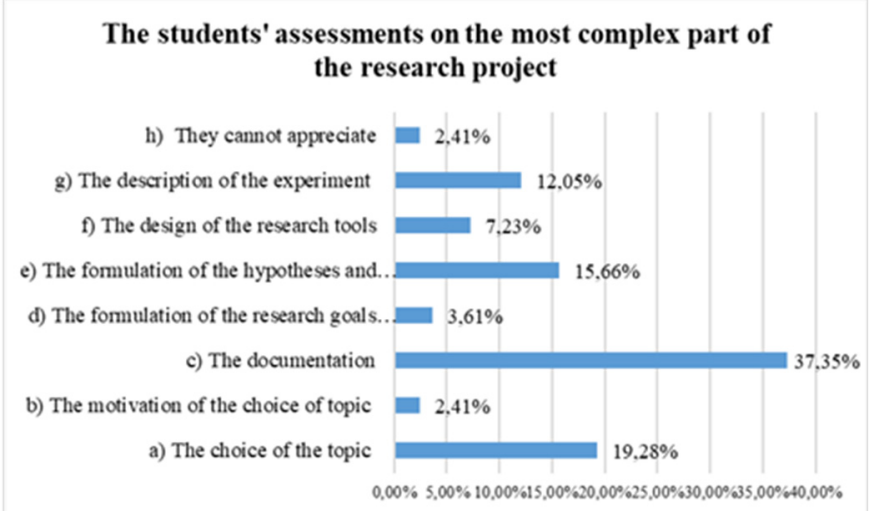

Figure no. 4. The students' assessments on the most complex part of the research project

Two of the questionnaire items, with open answers, asked for the students' opinion on the part of the research project they think they managed very well or not so well.

After centralizing the answers, we obtained the following hierarchy:

The best done part of the project:
The students' opinion on the part of the research project they consider they did best

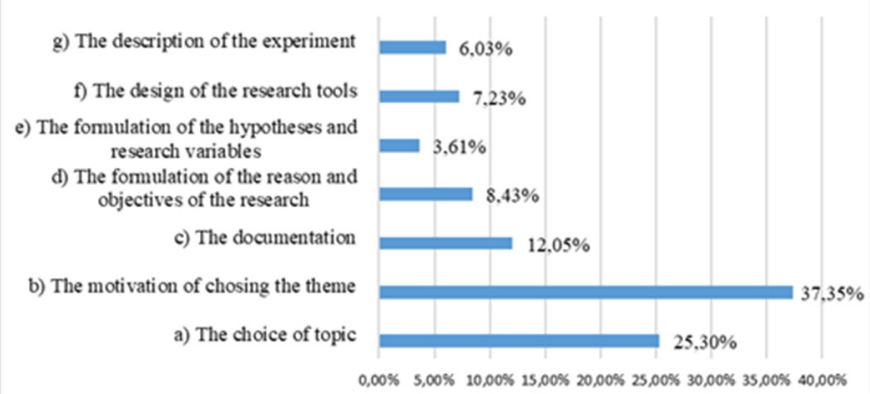

Figure no. 5. The students' opinion on the part of the research project they consider they did best

The least developed part of the project:

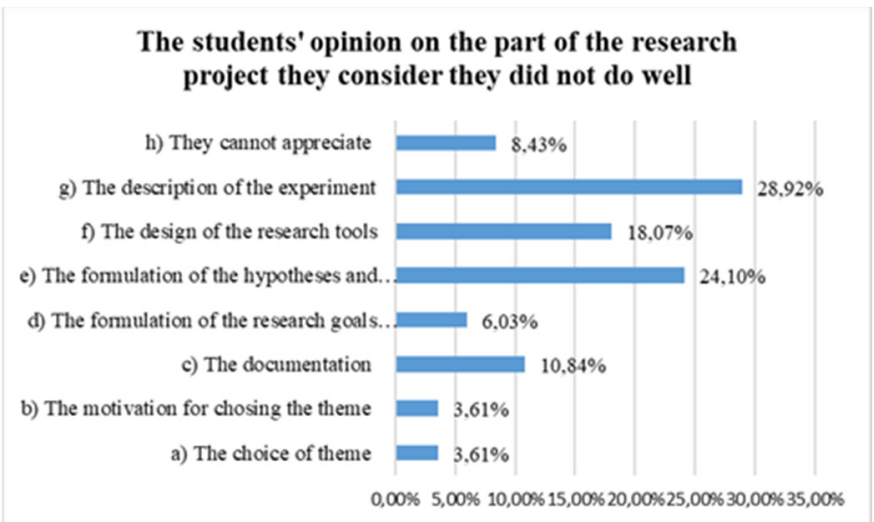

Figure no. 6. The students' opinion on the part of the research project they consider they did not do well

The following items of the questionnaire investigated the MA students' opinion on the difficulties they encountered during the different stages and sub-stages of the research project.

Thus, in motivating the choice of the theme, the students appreciated that they did not encounter difficulties in stating certain objective, scientific reasons (see figure no.7).

\section{The students' opinion on the difficulties encountered in motivating the choice of the theme}

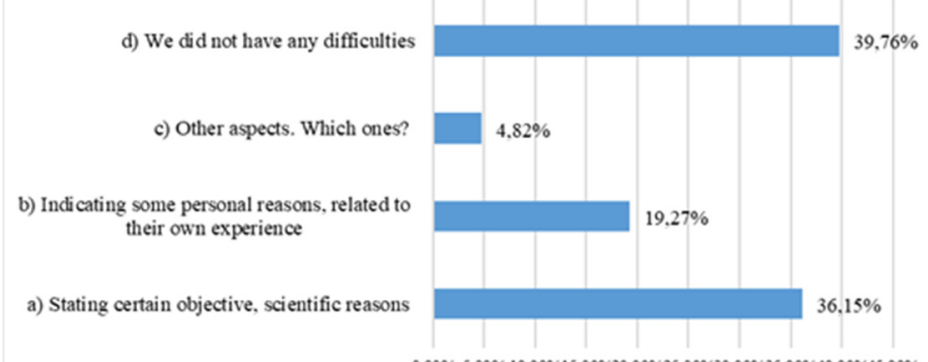

$0,00 \% 5,00 \% 10,00 \% 15,00 \%: 20,00 \% 25,00 \%, 30,00 \%, 35,00 \%$, $40,00 \%$ \%5, $00 \%$

Figure no. 7. The students' opinion on the difficulties encountered in motivating the choice of the theme 
Regarding the documentation, most of the students appreciated that they had difficulties in identifying some representative and current sources (figure no. 8).

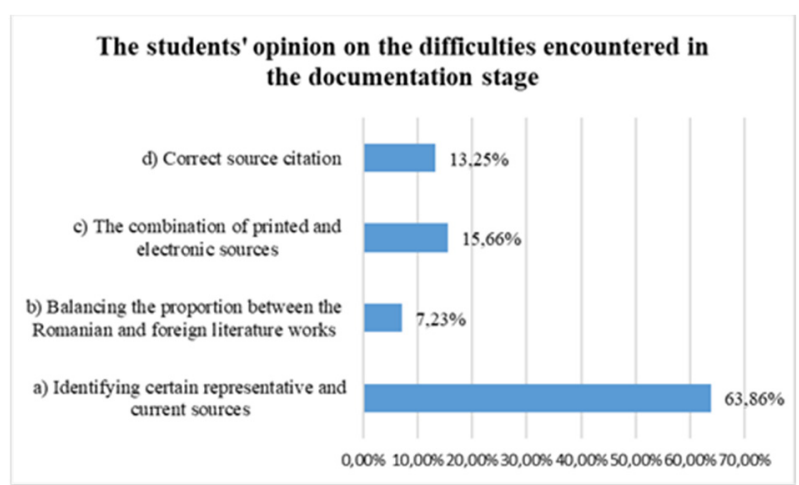

Figure no. 8. The students' opinion on the difficulties encountered in the documentation stage

The formulation of the purpose and objectives of the research has also been an important stage of the research. Figure no. 9 shows a situation of the difficulties they encountered.

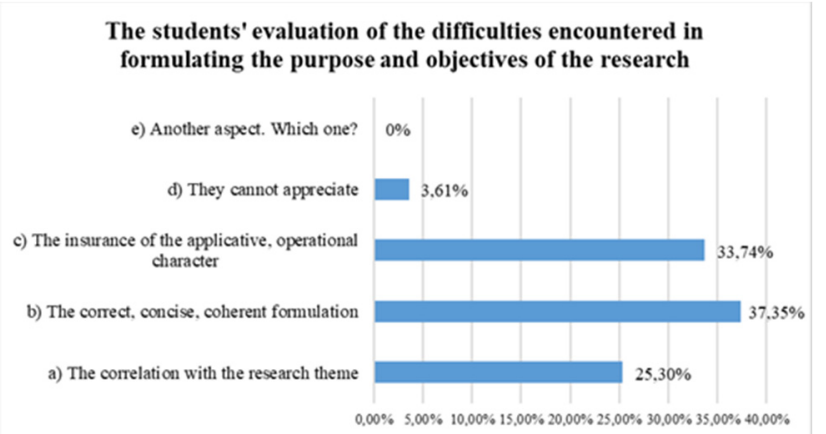

Figure no. 9. The students' evaluation of the difficulties encountered in formulating the purpose and objectives of the research

We are going to present in what follows the students' answers to the item that asked for their opinion on the difficulties encountered in formulating the research hypotheses (figure no. 10).

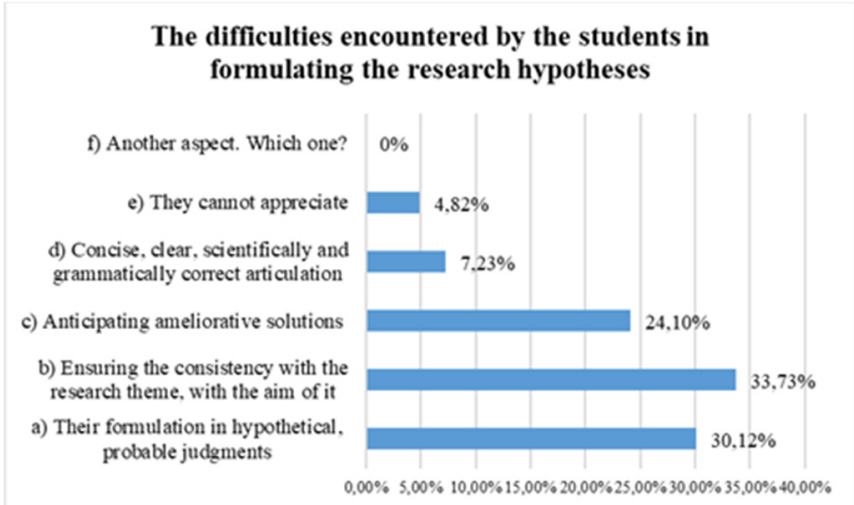

Figure no. 10. The difficulties encountered by the students in formulating the research hypotheses
The selection of the research methods and the indication of how to use them were the main obstacles students have encountered in choosing the research methodology, as can be observed in figure no. 11 .

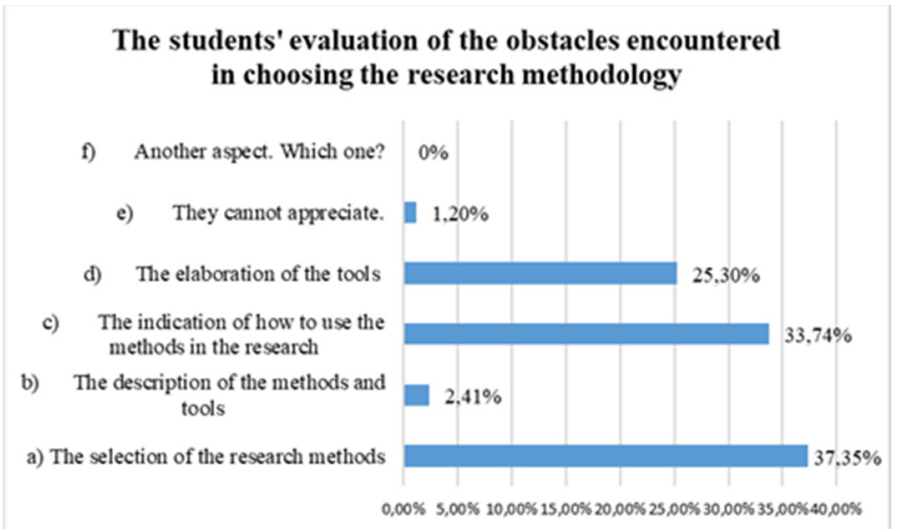

Figure no. 11. The students' evaluation of the obstacles encountered in choosing the research methodology

Figure no. 12 presents a hierarchy of the frequency with which the research methods were used. As you can see, the students mostly used the questionnaire and the interview, but also the test and the case study. In other methods, two students mentioned the sociometric test, and three respondents specified the observation.

We are stating that in this item the students had the possibility to choose more than one answers.

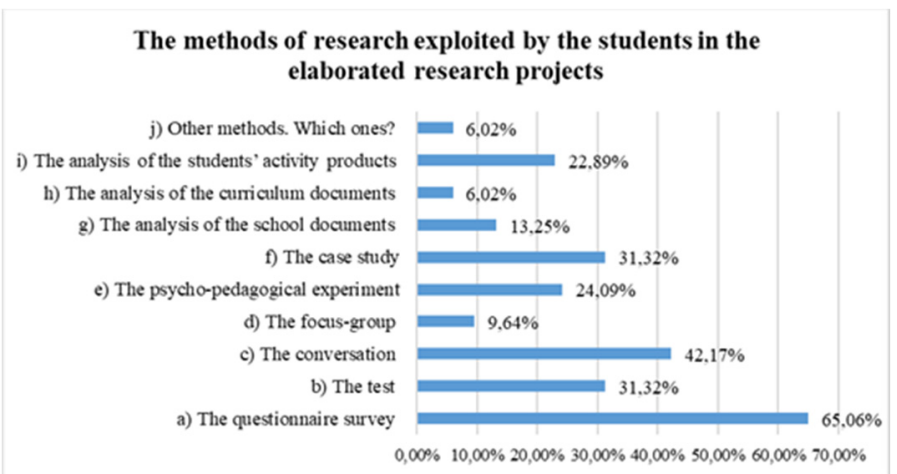

Figure no. 12. The methods of research exploited by the students in the elaborated research projects

The last two items have open answers and asked for the views of the subjects on the advantages and disadvantages of the pedagogical research project in the development of a future teacher's research skills.

Thus, among the advantages we mention:

- Acquiring new knowledge;

- The possibility to identify the current problems of education, as well as solutions; 
- $\quad$ Forming skills of synthesis, of formulating personal opinions, argumentation;

- Developing the competency of self-knowledge, of managing problem-situations, the metacognitive competency;

- Knowing new research methods;

- Performing activities with an applicative character;

- Developing professional competencies;

- The possibility of developing research tools;

- Exercising the ability to interpret the results of research, to disseminate them;

- Familiarizing with curriculum documents;

- Correlating all sources for carrying out research project in your own way.

As disadvantages or risks, the students mentioned:

- The duration of the research project;

- The need for extensive documentation;

- The choice of inappropriate themes;

- The difficulty to find sources for the chosen theme;

- The particular nature of the obtained results.

The opinions of the students were then confronted with the results of the evaluation of their portfolios. For the evaluation there was used a grid containing 22 indicators, grouped in four categories: on the choice of the theme, its formulation and the motivation of the choice, on the theoretical foundation, on stating the hypothesis and the objectives, on the choice of methodology. According to the recorded scores, difficulties were recorded:

- for the first category of indicators, the one regarding the applicative character and the possibility;

- for the topic to find ameliorative solutions;

- for the second category of indicators, in the indicators on the critical analysis of the sources, their;

- correct quote, a balance sheet of the more or less successful aspects from quoted sources, regarding the marking of their own contribution;

- for the third category, in the indicators on formulating the hypothesis as probabilistic statements;

- $\quad$ and in the requirement that the assumptions should address the real problems and find better solutions;

- $\quad$ for the last category - in the indicators describing the way in which the research methods are used.

Table no. 2. The evaluation grid

\begin{tabular}{lcc}
\hline Crt. & Indicators & Score \\
no. & & $(1-10)$
\end{tabular}

\begin{tabular}{ll}
\hline I. & $\begin{array}{l}\text { Concerning the choice and formulation of the theme and the } \\
\text { motivation of its choice }\end{array}$ \\
\hline I.1. & The theme is current and of general interest \\
\hline I.2. & It has an applicative character, it offers ameliorative possibilities \\
\hline I.3. & It benefits from sufficient theoretical support \\
\hline I.4. & The title is sufficiently limited in relation to the complexity of the theme \\
\hline II. & Concerning the theoretical foundation of the theme
\end{tabular}

II.1. The studied papers are considered reference points and they are current

II.2. Relevant webographics sources carefully selected are also valorized

II.3. The sources are critically analyzed

II.4. They are correctly recorded, both in the text and in the final bibliography

II.5. A balance sheet of the achieved and less achieved aspects is made

II.6. One's own contribution is marked

III. Specifying the hypotheses and research objectives 


\begin{tabular}{ll}
\hline III.1. & The hypotheses are formulated as statements of probable value \\
\hline III.2. & $\begin{array}{l}\text { The hypotheses address real problems and outlook ameliorative } \\
\text { solutions }\end{array}$ \\
\hline III.3. & There is a real concordance between the hypotheses and the theme \\
\hline III.4. & The formulation of the hypothesis is correct, concise, logical \\
\hline III.5. & The objectives are consistent with the assumptions \\
\hline III.6. & The formulation of the objectives is correct, concise, logical \\
\hline IV. & Choosing the research methodology \\
\hline IV.1. & $\begin{array}{l}\text { The methodology is consistent with the theme, the assumptions made and } \\
\text { the objectives set }\end{array}$ \\
\hline IV.2. & A description of the methods is made \\
\hline IV.3. & It is indicated how the methods are used in the research \\
\hline IV.4. & The research tools are described \\
\hline IV.5. & The research tools are attached \\
\hline IV.6. & It is indicated how to capitalize on the research results
\end{tabular}

\section{Discussions}

The results obtained after the application of the two research methods confirm, in part and in correlation, the importance of the designing of the pedagogical research in general, as well as the pedagogical research project, in particular.

Students were given the opportunity, during a semester, to practice their competence in designing pedagogical research, following all the stages and actions specific to such an approach.

Each stage of this algorithm has been exemplified and developed, depending on the type of each research. The pedagogical research project, developed by the students during the semester, was part of their final, summative assessment at the end of the semester.

The students conducted a detailed self-analysis of the project, objectively capturing the successful and less successful aspects of the papers. The complexity of such an instrument requires not only a serious theoretical foundation, but also a good knowledge of the educational reality and the difficulties it faces. As a result, a first challenge for the students was precisely the choice and formulation of the research theme.
The documentation stage, one of the important stages of the project design, was demanding for the students as they had to meet the criteria and requirements of a scientific documentation, to identify the relevant and upto-date sources, combining the possibilities offered by the printed texts with those offered by the Internet, and also use them correctly.

The greatest difficulties were encountered in the formulation of hypotheses and research variables. The difficulty comes first of all from the need to formulate hypothetical reasoning of some probabilistic statements, the truth value of which must be proved, demonstrated.

The students made a pertinent analysis of the advantages and disadvantages of the research project, mentioning, in particular, what was important to them, the practical utility of this instrument, its formative valences, especially from the perspective of a future teaching career.

The evaluation of the research projects, based on the presented grid, correlated with the students' opinion, expressed through the questionnaire confirmed the ideas already mentioned by the students. Following the application of the evaluation grid, we were able to identify the strengths and weaknesses of the research projects, we 
learned about the successful aspects but also the typical mistakes, all of which were reported to the students after the evaluation of the works.

We can argue that in this case there is an agreement between the students' self-evaluation and the teacher's evaluation.

\section{Conclusions}

Designing an activity, regardless of its specificity, is a necessary action to ensure the success of that activity, especially if we are dealing with a complex situation which involves a multitude of aspects, elements, variables. The design action is embodied in a tool that, beyond the relatively algorithmic structure, must have sufficient flexibility that does not limit the possibilities for action, thereby affecting the possibility of achieving the proposed finality.

The pedagogical research project is such an instrument that enables those who develop it to anticipate the research, as responses to the following key questions: What are they aiming at? How can I do it? What can I do it with? How do I capitalize on what I have achieved?

Although creativity is needed to develop the project, as mentioned before, we believe that in order to reach this level, it is necessary to have a previous, constant and sustained exercise that allows the formation of automatisms, the ability to design research, perfectly articulated, logical and unitary.

For prospective teachers, achieving this goal is possible by repeatedly being in the situation to elaborate some or all of the research, capitalizing on various themes in the educational field.

The present study offered the opportunity to appreciate the usefulness of the pedagogical research project in forming the research competencies of prospective teachers.

\section{Authors note:}

The authors have equal contributions to this article.

Florentin Remus MOGONEA, Associate Professor, Doctor of Education Sciences, Teacher Training Department, University of Craiova, permanent member of the Psycho-pedagogical Research Center, Editor of the Academic Publication Annals of the University of Craiova, Psychology-Pedagogy series. Competence fields: Pre- and in-service training of teachers; theory and practice of school assessment; management and leadership of the class of students; educational research; sociology of education.

Florentina MOGONEA, PhD Associate Professor, Teacher Training Department, University of Craiova, Director of the Psycho-pedagogical Research Center, Editor in-chief of the Academic Publication Annals of the University of Craiova, Psychology-Pedagogy series. Competence fields: Pre- and in-service training of teachers; theory and practice of school assessment; management and leadership of the class of students; educational research; sociology of education.

\section{References}

Abutabenjeh, S., Jaradat, R. (2018). Clarification of research design, research methods, and research methodology: A guide for public administration researchers and practitioners. Teaching Publishing Administration, 36(3), 237-258. Available at: https://doi.org/10.1177/0144739418775787 (accessed at 21.08.2019).

Astalin, P.K. (2013). Qualitative research design: A conceptual framework. International Journal of Social Science \& Interdisciplinary Research, 2(1), 118- 124. Available at: https://pdfs.semanticscholar.org/baa7/c8f5577b0b1798b5e9f 559f5cbae32bfla36.pdf (accessed at 21.08.2019).

Atieno, O.P. (2009). An analysis of the strengths and limitation of qualitative and quantitative research paradigms, Problems of Education in the 21 ${ }^{\text {st }}$ Century, 13, 13-18. Available at: http://www.scientiasocialis.lt/pec/files/pdf/Atieno_Vol.13.pd $\mathrm{f}$ (accessed at 19.08.2019).

Bocoș, M. (2003). Cercetarea pedagogică. Suporturi teoretice și metodologice. Cluj-Napoca: Editura Casa Cărții de Știință. Janssens, K.A.M., Bos, E.H., Rosmalen, J.G.M., Wichers, M.C. \& Riese, H. (2018). A qualitative approach to guide choices for designing a diary study. BMC Medical Research Methodology, 18(140), 1-12. Available at: https://doi.org/10.1186/s12874-018-0579-6 (accessed at 20.08.2019).

McKim, C.A. (2017). The Value of Mixed Methods Research: A Mixed Methods Study. Journal of Mixed Methods Research, 11(2) 202-222. Available at: https://doi.org/10.1177/1558689815607096 (accessed at 21.08.2019).

Mogonea, F. (2013). Fundamentele pedagogiei. Teoria și metodologia curriculumului. Sinteze teoretice şi instrumente aplicative pentru formarea profesorilor. Craiova: Editura Universitaria.

Mogonea, F.R. (2010). Pedagogie pentru viitorii profesori. Craiova: Editura Universitaria. 
Mohajan, H.K. (2018). Qualitative Research Methodology in Social Sciences and Related Subjects. Journal of Economic Development, Environment and People, 7(01), 23-48. Avilable at: https://mpra.ub.unimuenchen.de/85654/1/MPRA_paper_85654.pdf (accessed at 19.08.2019).

Plomp, T. (2013). Educational Research Design. An Introduction. In T. Plomp, N. Nieveen (eds.). Educational Research Design. Netherlands Institute for Curriculum Development (SLO). The Netherlands: Enschede. Available at: http://downloads.slo.nl/Documenten/educational-designresearch-part-a.pdf (accessed at 18.08.2019).
Seltman, H.J. (2012). Experimental design and analysis. Pittsburgh, PA: Carnegie Mellon University.

Toshkov, D. (2018). Research Design. In V. Lowndes, D. Marsh, G. Stoker. Theory and Methods in Political Science. London: Palgrave Macmillan, pp. 219-236.

Walliman, N. (2011). Research Methods the basics. London New York: Routledge.

White, H., Sabarwal, S. (2014). Quasi-experimental Design and Methods. Methodological Briefs: Impact Evaluation 8, UNICEF Office of Research, Florence. Available at: https://www.unicef-irc.org/KM/IE/img/downloads/QuasiExperimental_Design_and_Methods_ENG.pdf (accessed at 21.08.2019). 